\title{
Referential Value of the Cultural Exchange Experience of the Peace Corps for "People-to-People Bond" of Belt and Road Initiative
}

\author{
Long $\mathrm{Ye}^{1,2}$ \\ 1 ISCR, Macau University of Science and Technology \\ 2 School of Foreign Languages, Shaoguan University \\ Macau, China \\ bobyeesgu@163.com
}

\begin{abstract}
As the social foundation of the Belt and Road initiative, "People-to-People Bond" is the basis for cooperation between China and the countries along the Belt and Road. Through the grass-roots interaction, the US Peace Corps aims to promote mutual understanding between the United States and developing countries. Over more than half a century of history, the United States Peace Corps has achieved fruitful results in achieving the people-to-people exchanges between the United States and the host countries of the Peace Corps. The Peace Corps integrates foreign aid and cultural exchanges, attaches importance to grass-roots exchanges, pays attention to the training of volunteers' cross-cultural adaptability, and is good at spreading the influence of exchanges in the United States. These practices are worthy of reference in the link of the "People-toPeople Bond" of China's promoting Belt and Road Initiative.
\end{abstract}

Keywords-Belt and Road; People-to-People Bond; Peace Corps; Cultural exchange

\section{INTRODUCTION}

There is no doubt that the Belt and Road initiative will face various difficulties, risks and challenges. Among them, security risks and popular issues will be long-standing and difficult to solve, and to better mutual understanding between Chinese people and the people in countries along the Belt and Road is the most important issue. It is the fundamental way of the Belt and Road [1]. Since the Belt and Road initiative was put forward, China has paid more and more attention to promoting mutual understanding through humanities exchanges. A few government departments have formulated foreign humanities exchanges, and enterprises, institutions, and social organizations are increasingly participating in the external "humanities exchange" activities under the government's coordination, but the current humanities exchange practice activities have cognitive errors, and the work ideas are also inadequate [2]. The US Peace Corps is an independent federal government agency founded by the Kennedy Administration in 1961. Through the Peace Corps, the US government has dispatched nearly 230,000 Peace Corps volunteers to more than 140 developing countries [3], and has made important contributions in helping to achieve the mutual understanding between the American people and the people of the host countries of the Peace Corps. The experience of the Peace Corps in overcoming cultural differences and promoting mutual understanding is conducive to a deeper understanding of how to promote "People-to-People Bond" through humanities exchanges, and part of its experience is worth learning from the "People-to-People Bond" that serves the Belt and Road.

\section{THE INTEGRATION OF FOREIGN AID AND CULTURAL EXCHANGE}

The Peace Corps can be seen as a foreign aid project of the United States or as a cultural exchange program of the US government. The Peace Corps was formed in the special historical context of the Cold War and decolonization [4]. In the 1950s and 1960s, the US government realized that the flaws in American diplomatic practice at that time made the United States lack of awareness of newly independent developing countries and didn't have enough communication with these countries, which made the United States' image in these countries very negative. Thus, the original intention of the United States to form the Peace Corps was to achieve mutual understanding between the United States and developing countries through the Peace Corps. The threefold statutory objectives of the Peace Corps are: first, to provide interested countries with qualified volunteers to help these nations meet their needs for trained manpower; second, to help other people understand America better; and third, to help Americans understand other peoples of the world better [5]. The first of these three goals has the nature of foreign aid, while the second and third ones constitute cultural exchanges between the United States and the host countries. The first director of the Peace Corps, Sargent Shriver, denied the foreign aid nature of the Peace Corps. He believed that the main purpose of the Peace Corps was to promote mutual understanding between the United States and the host countries [6]. In fact, the effectiveness of the foreign aid of the Peace Corps is not obvious. But this does not mean that the Peace Corps' first purpose is not important. On the contrary, it is the foundation of the other two goals.

The human resources provided by the Peace Corps for its host country are different from the human resources provided 
by other foreign aid projects. The Peace Corps is not primarily to provide high-level scholars, technical experts and other talents to these countries, but mainly to provide them with relatively ordinary young men and women who have just graduated from college. Compared with technical experts, the aid for the host countries from those of "middle manpower" is limited. The assistance they provide and the efficiency of aid are limited. The majority of the Peace Corps budget is not used to finance the host country, but mainly for volunteers themselves. From these perspectives, it is difficult for the Peace Corps to become an efficient foreign aid project.

However, the Peace Corps' selection of volunteers and its unique way of doing things make its second and third goals carried out well. By recruiting volunteers who are mainly university graduates, the Peace Corps will send them to underdeveloped areas in developing countries, let them live the same life as locals, and work with local people to communicate with the grassroots for as long as two years to complete their volunteer work. Peace Corps volunteers have been through this approach, even though they believe that their work is of limited value to the host country, generally do not deny the contribution of their work to promoting mutual understanding [7]. However, we cannot deny the necessity of the existence of the Peace Corps' first purpose because it is the best reason for leaving volunteers in the host country for two years.

In addition, even if the work of the Peace Corps volunteers is not irreplaceable, the value of foreign aid they can bring cannot be completely ignored. At the very least, in most cases, they do not receive remuneration from the host country. That is to say they are free labor. Moreover, the Peace Corps' largest project, the educational program, can provide host countries with English teachers who speak authentic American language, which is urgently needed for many countries.

Therefore, we can say that the Peace Corps is a form of foreign aid for the purpose of promoting cultural exchanges.

\section{FOCUS ON THE GRASSROOTS}

The Ugly American published in 1958 caused a sensation in the United States. The American diplomats described in this novel made the United States disgraceful because they knew almost nothing about the country they live in, and they never touch the grassroots society [8]. These diplomats have no or even a negative effect on improving the image of the United States in developing countries and promoting mutual understanding between the United States and these countries. Although this work is a novel, it is a description based on the reality of the relationship between the United States and the newly independent third world countries.

The Peace Corps wants to use a way that does not rely on senior diplomats, but just like the "ugly" protagonists described in the novel, to achieve exchanges between the United States and the host country through contact with grassroots society. It is this starting point that makes the Peace Corps give priority to young men and women who have just graduated when recruiting volunteers. Because they have not formed the "airs" of experts or diplomats, they can afford the cost of serving two years in developing countries. Moreover, they can show the people of the host country the good side of the Americans.
In addition to the basic living allowance, the Peace Corps does not pay the volunteers. Their living allowances are tailored to the basic standard of living in the service area, and they would be sent in underdeveloped regions of developing countries. The living environment of the volunteers is basically the same as that of the local people. For example, they may need to live in a mud-hut like a farmer in Africa. They may live in a yurt like a Mongolian. They may need to walk to work like a local, or they may have to cook for themselves with firewood [9]. It is because of this that they can truly understand the social environment of the service area, understand the local cultural traditions, and make it easier to have deep communication with the local people.

In many cases, the exchanges brought about by the Peace Corps and the perception of the host country from the volunteers are those ignored by mainstream American media. This kind of exchange of the Peace Corps can be said to be the most solid "People-to-People Bond" between the United States and the host countries.

\section{The Training OF VOLUNTEERS' CROSS-CULTURAL ADAPTABILITY}

The Peace Corps has always focused on the training of volunteers' cross-cultural adaptability. After passing the rigorous application process of the Peace Corps, Peace Corps volunteers will receive a three-month pre-service training from the Peace Corps, and in-service training will be continued after the service begin. As mentioned earlier, the Peace Corps is more focused on the purpose of cultural exchanges, and the volunteer training provided by the Peace Corps also pays more attention to the cultural adaptation training of volunteers accordingly.

Unlike the training content of other foreign aid projects, a specific job skill is not the main content of Peace Corps volunteer training. If the Peace Corps is simply regarded as a foreign aid project, the training content of the volunteers should be based on job skills training. For example, if a volunteer does not have agricultural practice experience, but he wants to engage in agricultural projects after going to the host country, the training program should mainly focus on agricultural practical skills. But the Peace Corps' approach is not like this. The Peace Corps mainly considers the challenges brought by the cultural differences of volunteers after they go to the host country as the most important ones to be tackled. Therefore, most of the training content is focused on how to improve the cultural adaptability of volunteers. The largest section of the Peace Corps training content is language training, and in addition to language training, there will be training on culture and history of the host country. In order to better show the United States to the people of the host country, the training content will also include the history and culture of the United States.

From the perspective of training methods, the training of the Peace Corps has also paid more and more attention to the training of volunteers' cultural adaptability. The Peace Corps initially relied mainly on the strength of American universities to complete training, the trainers were mainly scholars or experts from universities and the training process was generally 
completed in American universities. However, in order to better imitate the environment of the host countries, special training bases were established for the training of volunteers for some countries. However, both of these methods are difficult to achieve a true environment in the service area. Therefore, starting from $1970 \mathrm{~s}$, the Peace Corps gradually placed the training in the host countries. Volunteer training in a host country where volunteers are about to engage in service work can help volunteers to improve their cultural adaptability when they are engaged in volunteer services.

The direct effect of this type of training by the Peace Corps is that the Peace Corps volunteers are able to prepare relatively well for the cultural differences in the service areas at the very beginning of the volunteer work and will tend to be more inclined to integrate with local culture in the subsequent volunteer work.

\section{THE SPREAD OF THE EXCHANGE EFFECT OF VOLUNTEERS}

For the American people, the communication effect brought by the Peace Corps is not limited to volunteers. The effects of cultural exchange by the Peace Corps volunteers will spread to more Americans in a wider field. The recruitment of volunteers for the Peace Corps is not limited to a specific profession. It is also because the professional background of the volunteers is rich and diverse, they will take up jobs in different fields after completing the volunteer work. Therefore, the influence of volunteer work in the host country will be brought into various fields of the United States. Volunteers' perceptions of host countries will also spread in various fields in the United States.

The Peace Corps encourages volunteers to write their own volunteer experiences as memoirs and publish them. The documentary publications of volunteers will enable more people to have a deeper understanding of the host countries. The description of a volunteer's experience in a memoir will always involve a large number of host country cultures and may correct previous misunderstandings or prejudices against the countries. That is, these contents not only show readers the cultural content of the host countries, but sometimes also enable readers to understand or sympathize with some of the cultural content they misunderstand. According to the US Library of Congress, there are no safety statistics, the Peace Corps volunteers have published more than 800 books on the host countries [10].

The "World Wise Schools" of the Peace Corps is another effective way to spread the cultural exchange effects of volunteers. The Peace Corps' "Paul D. Coverdell World Wise Schools" project was created in 1989 and is dedicated to bringing the interaction between the experience of Peace Corps volunteers and the education in the United States. American educators can use the "World Wise Schools" to bring the experience of volunteers to the classrooms in the United States remotely using forms such as "Web chat", "writing Exchange" and "Content Sharing". Not only do American educators be able to interact with volunteers who are serving in the host country through the program, but American students can also interact with students in the host country. Moreover, the project will expand the influence of the Peace Corps in the United States, making American students more interested in the Peace Corps' volunteer work and contributing to the Peace Corps' sustainable development.

\section{IMPLICATIONS FOR “PEOPLE-TO-PEOPLE BOND” OF BELT AND ROAD}

The success of the US Peace Corps and its experience in cultural exchanges has the following implications for promoting the "People-to-People Bond" of Belt and Road initiative.

First, China's assistance to countries along the Belt and Road can give due consideration to the possibility of combining foreign aid with cultural exchanges. China's assistance to some these countries should not only consider the consolidation of political and economic cooperation, but also make full use of these aid projects to strengthen communication and mutual understanding between the Chinese people and the people of these countries. The staff of China's foreign aid construction projects need to be more in touch with the local people. Priorities should be given to the projects with good foreign aid effects and good communication results. However, when developing new projects, considerations should also be made on the projects whose foreign aid effect is general but have the potential for outstanding communication effect.

Second, more attention should be paid to the improvement of the cultural adaptability of Chinese staff along the "Belt and Road". The living area of expatriates should not be limited to companies or within the project walls, and they should be bold enough and good at integrating into the local society. In addition to contacting local officials and project leaders, expatriates must deal with people in the local grassroots community. In order for expatriates to have these abilities, there should be a focus on the training of the foreign language and the history and cultural knowledge of the host countries.

Third, the exchange effect of expatriates should be maximized. Chinese employees who have been stationed abroad for a long time can show more Chinese citizens the culture and customs of the host country in the form of blogs, travel notes or memoirs. In an era when the internet is so advanced, there is no difficulty for China to make use of projects such as the Confucius Institute to create a Chinese version of "World Wise Schools".

\section{SUMMARY}

The Peace Corps' combination of foreign aid and cultural exchanges has some referential value for China's Belt and Road initiative to promote "People-to-People Bond" between the Chinese people and the people in countries along the Belt and Road. Lessons from the Peace Corps such as paying more attention to the communication and mutual understanding at the grassroots level, a focus on the training of volunteers' cultural adaptability, and the spread of effects of volunteers' experience of cultural exchange to more people in a wider field should be learnt by Belt and Road initiative to let ordinary Chinese citizens who are working in the host countries to better 
promote the link of "People-to-People Bond" between Chinese people and the people along the Belt and Road.

\section{REFERENCES}

[1] Jianfei Liu.(2017).The Fundamental Way of the Belt and Road is "People-to-People Bond". Theoretical Horizon,(6):1-1. (In Chinese)

[2] Liwei Zhuang. (2017). The Gap Between China's People-to-People Exchange Policy and Its Aim to Promote Understanding Among People. Southeast Asian Studies, (6), 67-84.(In Chinese)

[3] Peace Corps. (2018). The Peace Corps' Fiscal Year 2018 Congressional Budget Justification. Retrieved from Peace Corps: https://files.peacecorps.gov/multimedia/pdf/policies/peacecorps_cbj_201 8.pdf

[4] Cobbs, A Elizabeth. (1996). Decolonization, the Cold War, and the Foreign Policy of the Peace Corps. Diplomatic History, 20(1): 79-105.

[5] The Peace Corps Act. (1961). Retrieved from Peace Corps: https://files.peacecorps.gov/multimedia/pdf/policies/ms101.pdf.

[6] Shriver, Sargent. (1963). Two years of the Peace Corps. Foreign Affairs, 41(4): 694-707.

[7] Blatchford, H Joseph. (1970). The Peace Corps: Making it in the Seventies. Foreign Affairs, 49(1): 122-135.

[8] Burdick, Eugene, \& Lederer J William. (1959). The Ugly American. London: Victor Gollancz.

[9] Meisler, S. (2010). When the World Calls: the Inside Story of the Peace Corps and Its First Fifty Years. Boston, Massachusetts: Beacon Press.

[10] Library of Congress. (2011). Annotated Bibliography of Peace Corps Writers' Books in the Library of Congress. Retrieved from Library of Congress: https://www.loc.gov/peacecorps/BibliographyPeaceCorpsWriters.pdf. 